\title{
BMP-4 inhibits follicle-stimulating hormone secretion in ewe pituitary
}

\author{
M-O Faure, L Nicol ${ }^{1}$, S Fabre, J Fontaine, N Mohoric, \\ A McNeilly ${ }^{1}$ and $C$ Taragnat
}

UMR 6175 INRA-CNRS-Université de TOURS-Haras Nationaux, Physiologie de la Reproduction et des Comportements, 37380 Nouzilly, France

${ }^{1}$ Medical Research Council, Human Reproductive Sciences Unit, Centre for Reproductive Biology, The University of Edinburgh Chancellor's Building, 49 Little France Crescent, Old Dalkeith Road, Edinburgh EH16 4SB, UK

(Requests for offprints should be addressed to C Taragnat; Email: taragnat@tours.inra.fr)

\begin{abstract}
Activins and inhibins, members of the transforming growth factor-beta family are able to stimulate and inhibit, respectively, FSH synthesis and release. Other members of this superfamily, the bone morphogenetic proteins (BMPs), may also affect FSH synthesis in the mouse. The aim of this work was to determine whether BMPs are expressed in the ovine pituitary and whether they play a role in the regulation of FSH release.

The mRNAs encoding BMP-2, BMP-4, BMP-7 and the oocyte-derived growth factor, growth differentiation factor (GDF)-9 were detected in the pituitaries of cyclic ewes by reverse-transcriptase PCR, as well as the mRNAs encoding the BMP type I receptors, BMPR-IA (activinreceptor-like kinase (ALK)-3) and BMPR-IB (ALK-6), and type II receptors (BMPR-II). Immunolabeling of pituitary sections revealed the presence of BMPR-IA (ALK-3) and BMPR-II in gonadotrope cells. To investigate the potential effects of BMPs on FSH secretion, ewe
\end{abstract}

pituitary cell cultures were treated with BMP-4 $\left(10^{-11} \mathrm{M}\right.$ to $10^{-9} \mathrm{M}$ ) for $48 \mathrm{~h}$. Interestingly, FSH release was decreased in a dose-dependent manner. At $10^{-9} \mathrm{M}$ BMP-4 both FSH concentration and FSH $\beta$ mRNA expression were reduced by $40 \%$ of control values. In contrast, there was no inhibitory effect on either LH or LH $\beta$ mRNA expression. A similar result was found with BMP-6. BMP-4 triggered the phosphorylation of Smad1, suggesting that the effect of BMP-4 on FSH secretion is due to the activation of the BMPs signaling pathway. Furthermore, BMP-4 blocked the stimulatory effect of activin on both FSH release and FSH $\beta$ mRNA and amplified the suppression of FSH release and FSH $\beta$ mRNA levels induced by $17 \beta$-estradiol. These results indicate that a functional BMP system operates within the sheep pituitary, at least in vitro, to decrease FSH release and to modulate the effect of activin.

Journal of Endocrinology (2005) 186, 109-121

\section{Introduction}

In females the gonadotropins FSH and LH produced by pituitary gonadotropes are required for terminal follicular growth and regulation of ovulation number (McNeilly et al. 1992). The patterns of the synthesis and release of $\mathrm{LH}$ and FSH diverge in several physiological situations. However, the mechanisms involved in LH and FSH differential regulation are still unclear. Gonadotropin synthesis and release are orchestrated by an interplay of hypothalamic, gonadal and pituitary factors. The primary stimulus for synthesis and release of FSH and LH appears to be the hypothalamic gonadotropin-releasing hormone $(\mathrm{GnRH})$. Nevertheless, depending on pulse frequency or amplitude, GnRH exerts a differential effect on both hormones. While a high frequency of GnRH pulses is favourable to LH secretion, a low frequency is associated with the production of FSH (Dalkin et al. 1989, Molter-Gerard et al. 1999). Other factors such as gonadal steroids, progesterone and estrogens can also differentially modulate the secretion of LH and FSH (Mercer et al. 1993, Molter-Gerard et al. 2000). In addition to GnRH and steroids, some members of the transforming growth factorbeta (TGF- $\beta$ ) superfamily, particularly activins and inhibins, are involved in specific regulation of FSH production. Activin is a dimer of two $\beta$ subunits ( $A$ and $B$ ). The association of the subunits results in activin $A$, activin $B$ or activin $A B$, each of which increases FSH $\beta$ mRNA expression and FSH release (Carroll et al. 1989). Activins are produced by the gonads and the pituitary where they act as paracrine factors (Knight 1996, Bilezikjian et al. 2001, Welt et al. 2002, Lin et al. 2003). Inhibin is a dimer of an $\alpha$ subunit and either $\beta A$ or $\beta B$ subunits forming inhibin A or B respectively, each of which suppresses FSH synthesis and release (De Kretser \& Robertson 1989). They are produced mainly in the gonads and act through an endocrine pathway. Recently other molecules of the TGF- $\beta$ superfamily, the bone morphogenetic proteins (BMPs) were shown to play a role in FSH regulation (Huang et al. 2001, Otsuka \& Shimasaki 2002). 
Initially, BMPs were identified through their actions on bone morphogenesis. They are now known to have effects on growth, differentiation, apoptosis and other phenomena in many cell types (for review, Shimasaki et al. 2004). BMP signaling occurs through a heteromeric complex with a type BMPR-IA (ALK-3) or BMPR-IB (ALK-6) and type BMPR-II serine/threonine kinase receptors (Kawabata et al. 1998, Miyazono et al. 2001). The ligand binding induces the trans-phosphorylation of the type I receptor by the type II receptor. Consequently, the activated BMPR-I phosphorylates cytoplasmic proteins called receptor-activated Smads (R-Smads) which interact with a co-Smad, Smad4. BMP signaling recruits the specific R-Smads, Smad1, Smad5 and Smad8 and the $\mathrm{R}$-Smad-co-Smad complex translocates to the nucleus to promote specific gene expression (for review, Zwijsen et al. 2003).

It is now admitted that BMPs play a crucial role in reproduction. In sheep, natural mutations of the BMP system alter the ovulation rate. For instance, in the Inverdale, Hanna, Cambridge and Belclare phenotypes, mutations in the BMP-15 gene lead to hyperprolificity in heterozygous ewes, while homozygous ewes are sterile (Galloway et al. 2000). A mutation in GDF-9, associated with alterations in follicular development, has also been identified in Belclare and Cambridge sheep (Hanrahan et al. 2004). In the Booroola phenotype, hyperprolificity is associated with a mutation in the intracellular serine/ threonine kinase domain of the BMP receptor IB (Mulsant et al. 2001, Souza et al. 2001, Wilson et al. 2001). Several BMPs have recently been implicated as autocrine/ paracrine regulators of ovarian follicule development (Knight \& Glister 2003, Shimasaki et al. 2004 (review)). For instance, BMP-15 produced by oocytes stimulates granulosa cell proliferation (Otsuka et al. 2000). BMP-4 and BMP-7 expressed by theca cells affect follicle development (Lee et al. 2001) and enhance FSH action on granulosa cells by stimulating estradiol (Shimasaki et al. 1999, Souza et al. 2002, Glister et al. 2004) and decreasing progesterone production (Shimasaki et al. 1999, Fabre et al. 2003). Besides the regulatory role of BMPs in the ovary, little is known about the action of BMPs at the pituitary level, particularly in species other than rodents.

In mouse embryos, the role of BMPs in pituitary organogenesis is well documented. BMP-4 is required for induction and formation of the Rathke's pouch rudiment (Takuma et al. 1998) while BMP-2 acting with FGF-8 in opposite gradients determines gonadotrope cell differentiation (Ericson et al. 1998, Dasen et al. 1999). In the adult mouse pituitary, high concentrations of BMP-6 and BMP-7 stimulate the activity of transfected ovine FSH $\beta$ promoter and the release of FSH (Huang et al. 2001). In the adult rat pituitary, BMP-15 stimulates specifically FSH release (Otsuka \& Shimasaki 2002). Taken together, these data suggest that BMPs may act as regulatory factors in the pituitary, at least in rodents.
To extend our knowledge of FSH synthesis regulation, we investigated the potential role of BMPs in the ewe pituitary. Our data showed that BMP receptors and BMP-2, BMP-4, BMP-7 and GDF-9 mRNAs were present in the pituitary. Interestingly, BMP-4 and BMP-6 inhibited the FSH, but not the LH release from primary pituitary cells. In comparison with other physiological factors, we found that BMPs antagonized the activin effect known for stimulating FSH release and amplified the inhibitory action of $17 \beta$-estradiol. Thus, in the sheep pituitary BMP-4 and BMP-6 act to suppress FSH production.

\section{Materials and Methods}

\section{Reagents}

Cell culture reagents used were DMEM (Dulbecco's modified eagle's medium) and F12 (Nutrient mixture F-12 Ham) from Sigma (Saint Louis, MO, USA). Gentamicin, nistatine, L-ascorbic acid, apo-transferrin, FCS (fetal calf serum) and BSA (bovine serum albumin) were purchased from Sigma. Collagenase A and DNase I were from Roche Diagnostics Ltd (Meylan, France). Human recombinant Activin-A, BMP-6 and BMP-4 were obtained from R\&D systems (Lille, France). 17- $\beta$ estradiol was from Sigma. Rabbit antibodies against phosphorylated Smad1 and against Smad1 protein were from Upstate Biotechnology (Euromedex, Mundolsheim, France). Mouse monoclonal antibody directed against bovine LH $\beta$ (bLH $\beta$ 518B7) was obtained from J F Roser (Department of Animal Science, University of California, USA) (Matteri et al. 1987). Rabbit polyclonal antibody directed against BMPR-IA (amino acid 181-202; ten Dijke et al. 1994), BMPR-IB (amino acid 151-168; ten Dijke et al. 1994) and BMPR-II (amino acid 185-202; Rosenzweig et al. 1995) were kindly given by C H Heldin (Ludwig Institute for Cancer Research, Uppsala, Sweden).

\section{Tissue collection}

Pituitaries from Ile de France, Merinos d'Arles and Scottish Blackface ewes were collected throughout the year and dissociated for cell cultures or immersed in Bouin's Holland fixative containing $\mathrm{HgCl}_{2}$ for immunohistochemistry. Some pituitaries and ovarian follicles were used for RNA extraction.

\section{Reverse transcription-PCR on whole tissues}

Total RNA from ewe pituitaries and ovarian follicles were extracted using TRI Reagent (Sigma). Complementary DNA was synthesized from $1 \mu \mathrm{g}$ RNA in a volume of $20 \mu \mathrm{l}$ containing $150 \mathrm{ng}$ oligodT (Promega, Charbonnières, France), 
Table 1 Oligonucleotide primer sequences used for PCR (A) and Real-time PCR (B).

A PCR

\begin{tabular}{|c|c|c|c|c|c|}
\hline & Forward sequence & Reverse sequence & $\begin{array}{l}\text { Annealing } \\
\text { temperature } \\
\left({ }^{\circ} \mathrm{C}\right)\end{array}$ & $\begin{array}{l}\mathrm{MgCl}_{2} \\
\text { concentration } \\
(\mathrm{mM})\end{array}$ & $\begin{array}{l}\text { Product } \\
\text { size } \\
\text { (bp) }\end{array}$ \\
\hline \multicolumn{6}{|l|}{ Primer } \\
\hline BMP-2 & gTCACAgATAAggCCATTgC & ССТССАСАACAATgTCCTgA & 58 & $1 \cdot 5$ & 403 \\
\hline BMP-4 & ggTCACCTTIggCCATgATg & ACCTTgTCATACTCATCCAg & 58 & 2 & 359 \\
\hline BMP-6 & AAgCAgCCCTTCATggTggC & CATgTgTgCgTTgAgAgggA & 58 & 1 & 296 \\
\hline BMP-7 & AgAgCATCAACCCCAAgTTg & CgATgATCCAgTCCTgCCAg & 62 & 1 & 284 \\
\hline BMP-15 & ggATCACTggATCATTgCTC & gCAATCATACCСTCATACTC & 58 & $1 \cdot 5$ & 250 \\
\hline GDF-9 & TAgTCAgCTgAAgtgggACA & ACgACAggTACACTTAgTgg & 58 & 1 & 275 \\
\hline BMP-RIA & AACACATgCATAACTAATgg & ACCATCTgAATCTgTTTggC & 54 & $1 \cdot 5$ & 493 \\
\hline BMP-RIB & AgATTggAAAAggTCgCTATg & CgAgTgTTgggTggTATg & 54 & $1 \cdot 5$ & 486 \\
\hline BMP-RII & ATggAACATgACAACATTgC & CCTgggAAgAggTCTgTACA & 54 & $1 \cdot 5$ & 523 \\
\hline \multicolumn{6}{|c|}{ B Real time PCR } \\
\hline & Forward sequence & Reverse sequence & Probe & & \\
\hline \multicolumn{6}{|l|}{ Primer } \\
\hline $\mathrm{FSH} \beta$ & CACgAgggTgCTाTCCATT & TgggACCgTATCCCTAgCTTT & \multicolumn{3}{|c|}{ АATAATCTTAgAAАTССТСТСAggСААТСССТТССТС } \\
\hline $\mathrm{LH} \beta$ & ССgСТСССАgATATССТСТTС & TgCTggCTTIgggAgTTAgg & \multicolumn{3}{|c|}{ AAggATgCCССАСТTCAАТСТСССАТ } \\
\hline
\end{tabular}

$1 \mathrm{mM}$ dNTPs, $20 \mathrm{U}$ of RNasin, $1 \times \mathrm{RT}$ PCR buffer [from $5 \times$ assay buffer B $(250 \mathrm{mM}$ Tris- $\mathrm{HCl}(\mathrm{pH} 8 \cdot 3)$, $\left.\left.375 \mathrm{mM} \mathrm{KCl}, 15 \mathrm{mM} \mathrm{MgCl}_{2}, 50 \mathrm{mM} \mathrm{DTT}\right)\right]$, and $12 \mathrm{U}$ M-MLV reverse transcriptase (Promega). For the negative control, the reverse transcriptase was omitted. The RNA denaturation was performed at $70{ }^{\circ} \mathrm{C}$ for $10 \mathrm{~min}$ and the reverse transcription at $37^{\circ} \mathrm{C}$ for $1 \mathrm{~h}$. PCR was carried out in a volume of $25 \mu \mathrm{l}$ containing $2.5 \mu \mathrm{l} \mathrm{RT}$ reaction mixture, $1 \times$ PCR buffer [from $10 \times$ PCR buffer without $\mathrm{MgCl} 2(500 \mathrm{mM} \mathrm{KCl}, 100 \mathrm{mM}$ Tris $\mathrm{HCl}(\mathrm{pH}$ 9) and $1.0 \%$ Triton $\mathrm{X}-100), 50 \mathrm{pmol}$ of each primer, indicated concentrations of $\mathrm{MgCl}_{2}, 0 \cdot 2 \mathrm{mM}$ dNTPs and $10 \mathrm{U} \mathrm{Taq}$ polymerase (Promega). PCR reactions were performed for 30 cycles of $30 \mathrm{~s}$ at $94{ }^{\circ} \mathrm{C}, 2 \mathrm{~min}$ at indicated annealing temperature, and $3 \mathrm{~min}$ at $72{ }^{\circ} \mathrm{C}$. For primer sequences and details, see Table $1 \mathrm{~A}$.

\section{Immunohistochemistry}

After fixation and dehydration, sheep pituitaries were embedded in paraffin wax. Sections ( $5 \mu \mathrm{m}$ thickness) were dewaxed and re-hydrated in xylene then in decreasing concentrations of alcohol (100, 90 and 75\%). Antigen retrieval was performed by steaming the sections in a pressure cooker in citrate buffer $(0.01 \mathrm{M}) \mathrm{pH} 6.0$ for $5 \mathrm{~min}$, then cooled down for $20 \mathrm{~min}$. After two $5 \mathrm{~min}$ washes in PBS a combined avidin-biotin block was performed according to the manufacturer's instructions (Vector Laboratories, Peterborough, UK). Sections were incubated at $4{ }^{\circ} \mathrm{C}$ overnight with the monoclonal antibLH $\beta$ diluted 1:250 in PBS containing 20\% normal goat serum and 5\% BSA (PBS/NGS/BSA). Negative controls were performed by replacing the first antibody with normal goat serum. After washes in PBS-Tween 20 (0.05\%; PBST) and PBS, slides were incubated in goat anti-mouse Alexa 488 (Molecular Probes, Eugene, OR, USA) and diluted at 1:200 in PBS for $1 \mathrm{~h}$. After washes in PBS, slides were blocked in PBS/NGS/BSA for $30 \mathrm{~min}$. Sections were then incubated at $4{ }^{\circ} \mathrm{C}$ overnight with rabbit polyclonal antibody directed against BMPR-IA, BMPR-IB or BMPR-II diluted in PBS/NGS/BSA at $1: 100,1: 100$ and $1: 25$, respectively. Negative controls were performed by replacing either BMPR antibody with normal goat serum. After washes in PBST and PBS, slides were incubated with goat anti-rabbit biotinylated antibody (Dako, Cambridge, UK) and diluted 1:500 for $30 \mathrm{~min}$. After three 5 min washes in PBS, sections were incubated with streptavidin Alexa 546 (Molecular Probes) diluted at 1:200 in PBS/NGS/BSA and counterstained for $2 \mathrm{~min}$ with propidium iodure at 1:2000 for $2 \mathrm{~min}$. Sections from sheep ovaries were performed as positive controls (Souza et al. 2002). The slides were examined using LSN 510 meta confocal microscope.

\section{Sheep pituitary cell cultures}

Pituitaries were finely sliced and placed in F12 supplemented $(3 \mu \mathrm{g} / \mathrm{ml}$ gentamicin, $2 \mu \mathrm{g} / \mathrm{ml}$ nistatine, $5 \%$ FCS, $0.4 \mathrm{mg} / \mathrm{ml}$ collagenase A and $0.025 \mathrm{mg} / \mathrm{ml}$ DNase I) and incubated for $1 \mathrm{~h} 30$ in a shaking water bath at $37^{\circ} \mathrm{C}$ followed by manual dispersion through different sizes of syringe. Cells were then centrifuged at $100 \mathrm{~g}$ for $5 \mathrm{~min}$ and the pellet resuspended in culture medium (DMEM supplemented with $3 \mu \mathrm{g} / \mathrm{ml}$ gentamicin, $2 \mu \mathrm{g} / \mathrm{ml}$ nistatine, 
$100 \mu \mathrm{M}$ L-ascorbic acid, $5 \mu \mathrm{g} / \mathrm{ml}$ apo-transferrin and 5\% FCS). Cells were plated in 48-well plates at 200000 cells/well, 12 -well plates at $1 \times 10^{6}$ cells/well or 6 -well plates at $2 \times 10^{6}$ cells/well in $500 \mu l, 1 \mathrm{ml}$ or $2 \mathrm{ml}$ respectively of culture medium (DMEM with 5\% FCS), and allowed to attach for 2 days in a humidified atmosphere with $5 \% \mathrm{CO}_{2}$ in air at $37{ }^{\circ} \mathrm{C}$. Media were replaced with serum-free DMEM containing 0.1\% BSA. One hour later, the medium was changed and DMEM-0.1\% BSA alone (control) or supplemented with test substances at different concentrations (see Results) was added. Media were collected $48 \mathrm{~h}$ later to assay for FSH and LH.

\section{LH and FSH assays}

The concentrations of FSH and $\mathrm{LH}$ were determined using double antibody ELISA immunoassays for all experiments, except for the estradiol experiments. For these latter, performed in Scotland, radioimmunological assay (RIA) for FSH was used.

ELISA LH and FSH were assayed in duplicate aliquots of pituitary cell culture supernatants. For LH, microtitration plates (Maxisorp C96, Nunc, France) were coated overnight at $4{ }^{\circ} \mathrm{C}$ with $100 \mu \mathrm{l} /$ well of a monoclonal antibody to bovine LH $\beta$-subunit 518B7 (Matteri et al. 1987) and diluted 1:3200 in carbonate buffer. Plates were then washed and blocked with PBS pH $7 \cdot 4$ containing $0 \cdot 09 \%$ Tween 20 and 12.5\% Sea-Block (Pierce, Brebières, France). Purified ovine LH (oLH CY1083) used as standard, controls and supernatants were added at $20 \mu \mathrm{l} /$ well along with $80 \mu \mathrm{l} /$ well of dilution medium (PBS containing $0.09 \%$ Tween 20, 12.5\% Sea-Block and 2\% normal rat serum). Plates were incubated overnight at $4{ }^{\circ} \mathrm{C}$. After removal of unbound material, biotinylated monoclonal antibody to human $\alpha$-subunit (Dirnhofer et al. 1994) diluted at $23 \mathrm{ng} / 100 \mu \mathrm{l} /$ well in PBS containing $0 \cdot 1 \%$ Tween 20 and $1 \%$ rat serum was added for $1 \mathrm{~h}$ at $37^{\circ} \mathrm{C}$. Plates were washed and horseradish peroxidaselabelled neutravidin (Pierce) was added at $25 \mathrm{ng} / 100 \mu \mathrm{l} /$ well. After $25 \mathrm{~min}$ at room temperature in obscurity and washing, peroxidase activity was developed with $100 \mu \mathrm{l}$ tetramethylbenzidine/well (Dako) for $30 \mathrm{~min}$ at room temperature. The reaction was stopped with $50 \mu \mathrm{l} \mathrm{Hcl} /$ $\mathrm{H} 2 \mathrm{SO} 4 / \mathrm{H} 2 \mathrm{O}(1 \mathrm{v} / 1 \mathrm{v} / 6 \mathrm{v})$ per well and the signal was measured at $450 \mathrm{~nm}$ and $620 \mathrm{~nm}$. The minimum detectable concentration for $\mathrm{LH}$ was $0.1 \mathrm{ng} / \mathrm{ml}$. The intra- and inter-assay coefficients of variation of the control averaged $4 \%$ and $10 \%$, respectively. The cross-reaction with oFSH was $0 \cdot 01 \%$.

For FSH, concentrations were measured as described for LH assay with the following modifications. Plates were coated overnight at $4{ }^{\circ} \mathrm{C}$ with $100 \mu \mathrm{l} /$ well of a monoclonal antibody to ovine FSH $\beta$ subunit (Henderson et al. 1995) and diluted 1:100 in carbonate buffer. Purified ovine FSH (NIH RP2) used as standard, controls and supernatants were added at $50 \mu \mathrm{l} /$ well along with $50 \mu \mathrm{l} /$ well of dilution medium. The minimum detectable concentration for FSH was $0.2 \mathrm{ng} / \mathrm{ml}$. The intra-and inter-assay coefficients of variation of the control were $2 \cdot 6 \%$ and $2 \cdot 1 \%$, respectively. The cross-reaction with oLH was $0 \cdot 07 \%$.

RIA RIA assay on ovine FSH was previously described (McNeilly et al. 1976, 1986). The sensitivity of the FSH RIA was $0.1 \mathrm{ng} / \mathrm{ml}$ and the intra- and inter-assay coefficients of variation were less than $10 \%$.

\section{Quantitative RT-PCR from pituitary cell cultures}

Ovine FSH $\beta$ and LH $\beta$ primers and probe were designed using Primer Express software (PE Biosystems, Warrington, Cheshire, UK) and synthesized by PE Biosystems (Table 1B). Ribosomal 18S primers and probe were from a Taqman RNA Control Reagents kit (VIC labeled probe; PE Biosystem).

Total RNA from 12-well plates were extracted using the Agilent Total RNA Isolation Mini Kit. RNA concentration was measured using RNA 6000 Nano Assay (Agilent Technologies, Stockport, UK). Aliquots of total RNA were treated with DNase I using DNA-free (Ambion Ltd, Huntingdon, Cambs, UK) according to manufacturer's protocol. Samples were then reverse transcribed, using oligod(T)16, with Taqman Reverse Transcription Reagents (PE Biosystems) according to the manufacturer's protocol, using a program of $10 \mathrm{~min}$ at $25^{\circ} \mathrm{C}, 30 \mathrm{~min}$ at $48^{\circ} \mathrm{C}$ and $5 \mathrm{~min}$ at $95^{\circ} \mathrm{C}$. DNasetreated RNA was approximatively added at $25-50 \mathrm{ng} / \mu \mathrm{l}$. For PCR, a reaction mix was prepared consisting of Taqman Universal PCR Master Mix $(1 \times)$, FSH $\beta$ or LH $\beta$ forward and reverse primers (300 nM each), FSH $\beta$ or LH $\beta$ probe $(200 \mathrm{nM})$, ribosomal $18 \mathrm{~S}$ forward and reverse primers (50 $\mathrm{nM}$ each) and ribosomal $18 \mathrm{~S}$ probe $(200 \mathrm{nM})$. This was aliquoted for each sample in separated tubes, then cDNA was added at $1 \mu \mathrm{l} / 25 \mu \mathrm{l}$ reaction mix (equivalent to 25-50 ng total RNA/25 $\mu \mathrm{l}$ ). Aliquots of $25 \mu \mathrm{l}$ were dispatched into a 96-well PCR plate, with each sample added in duplicate, optical caps fixed onto the plates and the PCR reaction run on an ABI Prism 7900 PCR machine (PE Biosystems) using standard conditions. Controls including cDNA prepared without Multiscribe reverse transcriptase enzyme were done to check for efficiency of DNAse treatment. Prior to analysis, a validation assay was performed to demonstrate that amplification of FSH $\beta$ gene and the reference (18S) were approximately equal, whereas the amplification of LH $\beta$ gene and $18 \mathrm{~S}$ were not equal. FSH $\beta$ and LH $\beta$ mRNA quantifications were performed by the $\Delta \Delta \mathrm{Ct}$ method and the standard curve method respectively (Bulletin number 2; PE Biosystems). A standard PCR reaction using the FSH $\beta$ and the LH $\beta$ primers was run on an agarose gel to confirm amplification of a single product of the correct size. 


\section{Western blotting analysis of Smad proteins}

To investigate Smad-1 activation by BMP-4, ewe pituitary cells were cultured at $2 \times 10^{6}$ cells/well in 6-well plates for $48 \mathrm{~h}$. Media were changed to remove nonattached cells and replaced by fresh media containing serum-free DMEM-0.1\% BSA alone or supplemented with $10^{-9} \mathrm{M}(50 \mathrm{ng} / \mathrm{ml})$ of BMP-4 for 30, 60 and $90 \mathrm{~min}$. Cells were then washed once on ice with cold PBS and lysed in lysis buffer $(150 \mathrm{mM} \mathrm{NaCl}, 10 \mathrm{mM}$ Tris pH 7·4, 1 mM EDTA, 1 mM EGTA, 1\% Triton X-100, 0.5\% Igepal CA-630, $100 \mathrm{mM}$ sodium fluoride, $10 \mathrm{mM}$ sodium pyrophosphate, $10 \mathrm{mM}$ sodium orthovanadate, proteases inhibitor cocktail). The concentrations of the proteins were determined with BC Assay Protein Quantitation kit (Interchim, Montluçon, France). After $1 \mathrm{~min}$ at $95^{\circ} \mathrm{C}$ in the reducing SDS-PAGE buffer containing $\beta$-mercaptoethanol, $15 \mu \mathrm{g}$ proteins were separated in $10 \%$ SDS-PAGE gels and electroblotted onto Immobilon-P membranes (Millipore corporation, Bedford, MA, USA). Membranes were blocked for $1 \mathrm{~h}$ at room temperature in Tris-buffered saline- $0 \cdot 1 \%$ Tween containing 5\% fat-free dry milk and incubated with the antiphospho Smad1 or the anti-Smad1 protein diluted at 1:4000 and 1:1000, respectively, overnight at $4{ }^{\circ} \mathrm{C}$. After washing, the membranes were incubated with the secondary antibody, a peroxidase-conjugated anti-IgG (Biorad, Marnes la Coquette, France) diluted 1:10000 for $1 \mathrm{~h}$. Immunoreactive proteins were detected using enhanced chemiluminescence reagents (Amersham Pharmacia Biotech, Orsay, France). Membranes were exposed to Hyperfilm ECL (Amersham Pharmacia Biotech) for 5 min.

\section{Statistical analysis}

Results are reported as mean \pm S.E.M. All experiments were performed in triplicate in at least three different experiments. For each figure, the number of experiments shown is indicated in the legend. The effects of increasing doses of BMP-4 on FSH concentrations were analysed by one-way ANOVA followed by Newman-Keuls post-test. The time course experiment was analysed by two-way ANOVA followed by Bonferroni post-test in order to appreciate the 'time effect' as well as the 'ligand' effect. Comparison between BMP-4 or BMP-6 and control groups on FSH and LH hormone concentrations and mRNA expression levels were analysed by an unpaired t-test. Comparison between BMP-4, activin, BMP-4 plus activin, estradiol, BMP-4 plus estradiol and control groups on FSH hormone concentrations and FSH $\beta$ mRNA expression levels were analysed by one-way ANOVA followed by Newman-Keuls post-test. $P<0 \cdot 05$ was considered significant. The statistical analysis was performed using the GraphPad Prism version 4.00 program for Windows (GraphPad Software, San Diego, CA, USA: www.graphpad.com).

\section{Results}

BMPs and BMP receptors are expressed in the ewe pituitary

To test whether ewe pituitary cells express BMP receptors and BMPs, RT-PCR was performed on Ile de France and Merinos d'Arles ewe pituitaries using primers described in Table 1A. After 30 cycles, DNA fragments were detected at expected sizes for BMP-2, BMP-4, BMP-7, GDF-9, BMP-RIA (ALK-3), BMP-RIB (ALK-6) and BMP-RII (Fig. 1A, B). No PCR product was detected for BMP-6 and BMP-15 in the pituitary. Positive controls were done on sheep ovarian follicles. In follicles, DNA fragments were observed for BMP-6 and BMP-15 (Fig. 1C, D). When negative controls were performed by omitting reverse transcriptase in the $\mathrm{RT}$ reaction, no PCR products were detected (not shown). Sequencing of all fragments confirmed product identity.

\section{BMP receptors $I A$ and $I I$ are present in gonadotrope cells}

Immunohistochemistry analysis revealed BMPR-IA, BMPR-IB and BMPR-II positive cells in the pituitary. The vast majority of cells bearing the BMPR-IA and BMPR-II are identified as gonadotropes by colocalization of BMPR-IA or BMPR-II and LH immunoreactivity (Fig. 2A, C). In contrast, BMPR-IB did not colocalize with LH (Fig. 2B).

BMP-4 and BMP-6 inhibit FSH secretion and $m R N A$ levels in the ewe pituitary

To determine whether BMPs were capable of modifying gonadotropin release from the ewe pituitary, cells were incubated with BMP-4. A dose-response study showed that treatment of cells with BMP-4 for $48 \mathrm{~h}$ inhibited FSH secretion from pituitary cells in a dose-dependent manner (Fig. 3A). The maximal inhibition of BMP-4 on FSH release was obtained with concentrations from $5 \times 10^{-10} \mathrm{M}(25 \mathrm{ng} / \mathrm{ml})$. A time course experiment showed that significant effect with BMP-4 at $10^{-9} \mathrm{M}$ $(50 \mathrm{ng} / \mathrm{ml})$ was observed from $24 \mathrm{~h}$ (Fig. 3B). When $10^{-9} \mathrm{M}$ BMP-4 were used to treat cells for $48 \mathrm{~h}$ in additional experiments, we confirmed that BMP-4 inhibited FSH release by $40 \%(P<0 \cdot 01)$ compared with control (Fig. 4A). LH release was not decreased (Fig. 4B). Similarly, FSH $\beta$ mRNA expression was decreased by $30-40 \%$ $(P<0 \cdot 05)$ but not LH $\beta$ mRNA expression (Fig. 4C, D). When cells were treated with $2 \times 10^{-9} \mathrm{M}(100 \mathrm{ng} / \mathrm{ml})$ BMP-6 for 48 h, a similar inhibitory effect on FSH release was observed (Fig. 4E, F). These inhibitory effects of BMPs were found for Ile de France, Merinos d'Arles and Scottish Blackface ewes.

\section{BMP-4 stimulates the BMP signaling pathway}

To determine whether BMP-4 could activate the BMP signaling pathway, proteins were extracted after 30, 60 or 
Pituitary

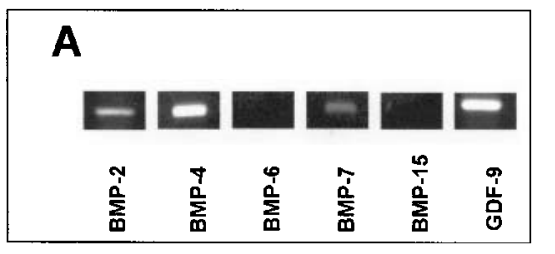

\section{B}

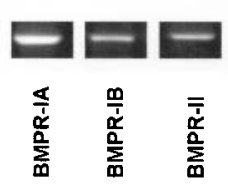

Ovarian Follicles
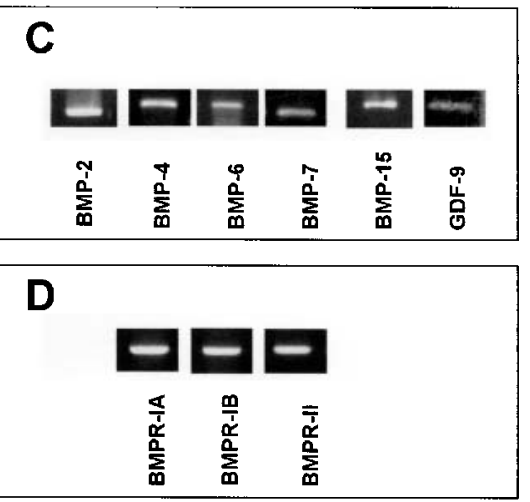

Figure 1 Expression of BMP ligands and receptors in sheep pituitary and ovarian follicles. Total RNA was extracted from sheep pituitaries $(A, B)$ and ovarian follicles $(C, D)$. The mRNAs encoding BMP ligands $(A, C)$ and receptors $(B, D)$ were analysed by RT-PCR at 30 cycles. DNA fragments were electrophoresed in $1 \%$ agarose gel and visualized by ethidium bromide staining.

90 min treatment with $10^{-9} \mathrm{M}$ BMP-4. The activation of Smad-1 was followed by western blot analysis using an antibody which recognizes the dual serine phosphorylated Smad-1 (Ser 463/465) with an apparent molecular weight of $65-66 \mathrm{kDa}$ in the phosphorylated state. Figure 5 shows that BMP-4 induced the apparition of a $66 \mathrm{kDa}$ band within $30 \mathrm{~min}$. The lower band observed on the blot corresponded to a non-specific band. In control samples harvested at the same time points, no phospho Smad1 immunoreactivity was detected. For Smad-1 protein, the intensity of the band did not change between control and BMP treatment (Fig. 5).

\section{BMP-4 antagonises activin effects}

To test whether BMP-4 was able to counteract the stimulatory effect of activin on FSH secretion and FSH $\beta$ mRNA expression, cells were incubated with both $2 \times 10^{-9} \mathrm{M}$ activin $(50 \mathrm{ng} / \mathrm{ml})$ and $10^{-9} \mathrm{M}$ BMP-4. BMP-4 antagonised the activin effect on FSH secretion (Fig. 6A) and on FSH $\beta$ mRNA levels (Fig. 6B).

\section{BMP-4 amplifies the effect of $17-\beta$ estradiol}

To test whether BMP-4 was able to amplify the inhibitory action of estradiol on FSH production, the effects of simultaneous treatment with BMP-4 and $17-\beta$ estradiol were determined. A dose-response study showed that $17-\beta$ estradiol inhibited the FSH secretion from pituitary cells in a dose-dependent manner (Fig. 7A). At $10^{-12} \mathrm{M}$, $17-\beta$ estradiol inhibited by $30-40 \%$ FSH release $(P<0 \cdot 05$ vs control) and maximal inhibition (around $70 \%$ ) was obtained with $10^{-11} \mathrm{M}(P<0 \cdot 001$ vs control; $P<0 \cdot 05$ vs $\left.10^{-12} \mathrm{M}\right)$. FSH $\beta$ mRNA expression was decreased by $80 \%\left(P<0 \cdot 001\right.$ vs control) with $10^{-11}$ M $17-\beta$ estradiol
(Fig. 7B). When cells were incubated with both BMP-4 $\left(10^{-9} \mathrm{M}\right)$ and $17-\beta$ estradiol $\left(10^{-12} \mathrm{M}\right.$ or $\left.10^{-11} \mathrm{M}\right)$, a stronger inhibition of FSH release was observed compared with either factor alone (Fig. 7A). This was also observed on FSH $\beta$ mRNA levels when cells were treated with both BMP-4 $\left(10^{-9} \mathrm{M}\right)$ and $17-\beta$ estradiol $\left(10^{-11} \mathrm{M}\right)$ (Fig. 7B).

\section{Discussion}

The synthesis and the secretion of the gonadotropins are differentially regulated by $\mathrm{GnRH}$, ovarian hormones and pituitary factors. Control of FSH production includes specific factors belonging to the TGF- $\beta$ superfamily, activin and inhibin. Recent data in rodents emphasize the potential role of other members of the same family, the BMPs, in the regulation of FSH synthesis and release (Huang et al. 2001, Otsuka \& Shimazaki 2002). We investigated here whether BMPs could participate to control FSH synthesis and secretion in the ewe. We first demonstrated that ewe pituitary does express a set of BMP mRNAs, BMP-2, BMP-4, BMP-7 and GDF-9. Furthermore, BMP type IA (ALK-3) and II receptors are present in the gonadotrope cells suggesting that a functional BMP system can act within the pituitary. Indeed, we observed that BMP-4 and BMP-6 decreased FSH $\beta$ mRNA expression and FSH release from ewe pituitary cells, whereas similar inhibitory effects were not observed on $\mathrm{LH}$ secretion.

The presence of BMP-2, BMP-4 and BMP-7 mRNA in the adult ovine pituitary corroborates the results of Souza et al. (2003). Moreover, for the first time, GDF-9 mRNA, known to be specifically expressed in oocyte (Yan et al. 2001) was detected in the pituitary. However, 

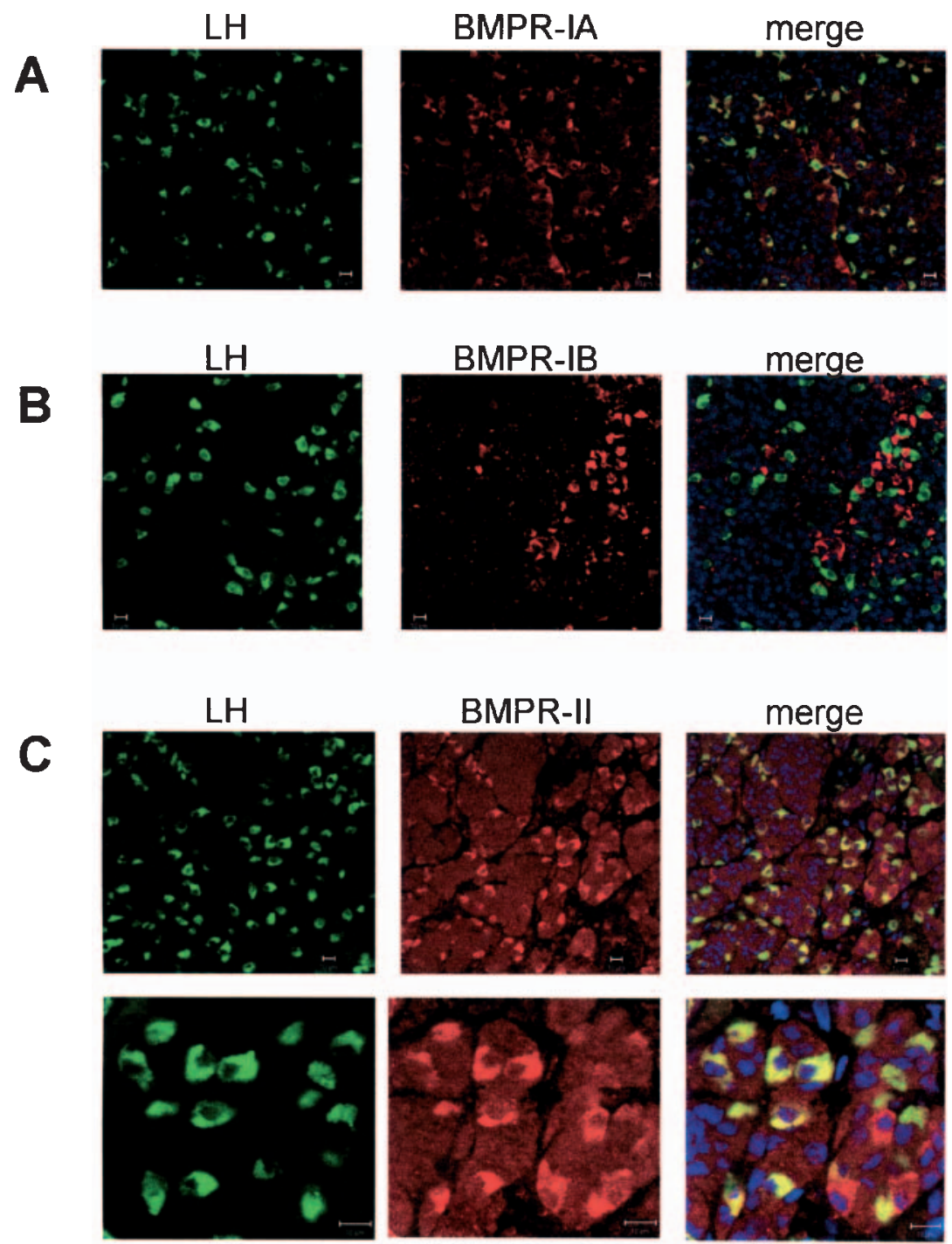

Figure 2 Immunohistochemical double staining for BMPR and LH. BMPR-IA, BMPR-IB and BMPR-II proteins were detected in the pituitary by immunohistochemistry. Ewe pituitary sections were incubated with mouse monoclonal antibody directed against LH $(1: 250)$ to detect gonadotrope cells followed by goat Alexa 488-conjugated anti-mouse IgG. In a second step, the same sections were incubated with rabbit polyclonal antibodies directed against BMPR-IA (1:100) (A), BMPR-IB (1:100) (B) or BMPR-II (1:25) (C) followed by goat anti-rabbit biotinylated antibody and then Alexa 546 labelled streptavidin. Nuclei were counterstained with propidium iodure. Most BMPR-IA and BMPR-II positive cells are also positive for LH. BMPR-IB positive cells are not positive for $\mathrm{LH}(\mathrm{B})$. Bar $=10 \mu \mathrm{m}$.

we did not detect BMP-6 and BMP-15 mRNA in ewe pituitary after 35 PCR cycles, whereas they are clearly observed in the ovarian follicles. In the mouse, these mRNAs appeared in the pituitary after more than 30-35 cycles (Huang et al. 2001, Otsuka \& Shimazaki 2002). Hence, the pattern of BMP expression appears to be different among species. In the ewe, our results suggest than BMP-2, BMP-4, BMP-7 and GDF-9 could have important actions at the pituitary level. Because BMP-4
mRNA was strongly expressed in pituitary, we examined its effect on FSH $\beta$ expression and FSH release in the ewe pituitary cells in primary culture. The effect of BMP-6 reported as an FSH stimulator in mouse pituitary by Huang et al. (2001) was also examined. The findings of inhibitory effects of both BMP-4 and BMP-6, at low concentrations, on FSH $\beta$ mRNA expression and FSH release from ewe pituitary cells were unexpected. Indeed, similar doses of BMP-6 and BMP-7 had no effect on FSH 

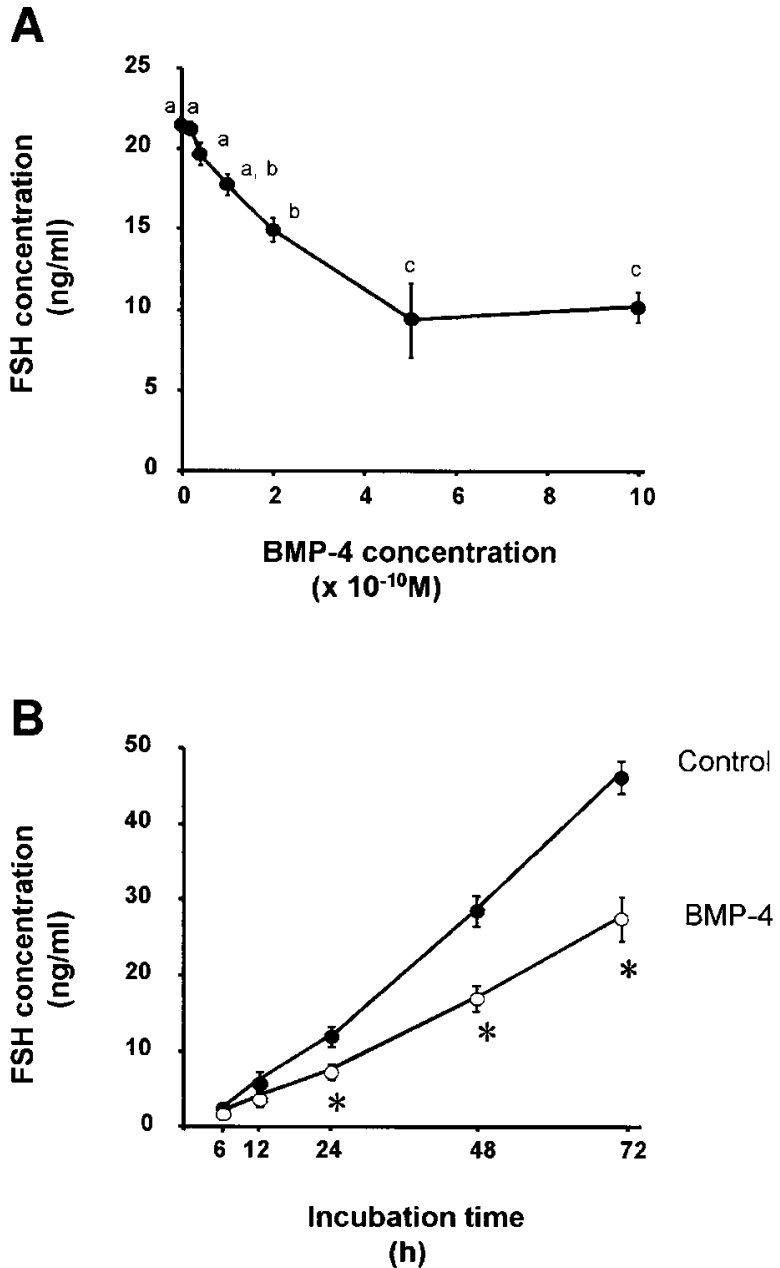

Figure 3 Dose response (A) and time course (B) of BMP-4 on FSH release from ewe pituitary cells. For the dose response, cells were cultured in serum-free medium for $48 \mathrm{~h}$ in the presence of indicated concentrations of BMP-4. For the time course, cells were cultured in serum-free medium in the presence or absence (control) of $10^{-9} \mathrm{M}$ of BMP-4 for indicated times. Media were collected and the concentrations of FSH were determined by ELISA. Values are the mean \pm S.E.M. from one representative experiment with triplicate determinations. Three experiments were performed with similar results. a vs $b, P<0.05$; a vs $c, P<0.0001 ; b$ vs $C, P<0 \cdot 01:{ }^{*}, P<0 \cdot 05$ vs respective control.

synthesis and secretion in mouse pituitary cells or the gonadotrope cell line, L $\beta$ T2 (Yamashita et al. 1995, Huang et al. 2001, Otsuka \& Shimasaki 2002) while a much higher concentration $\left(1 \mu \mathrm{g} / \mathrm{ml}\right.$, i.e. $\left.2 \times 10^{-8} \mathrm{M}\right)$ increased FSH transcription and secretion. Another BMP, BMP-15 exhibited a stimulatory effect in rodents (Otsuka \& Shimasaki 2002). The inhibitory effect of BMP-4 on ovine FSH production was not accompanied with an effect on pituitary cell proliferation as judged by the absence of changes in pituitary cell number after BMP treatment (data not shown). In mouse experiments, it has been suggested that BMP-6 and BMP-7 could transduce an activin-like signal since certain BMPs can bind to activin type II receptor present on mouse gonadotropes (Yamashita et al. 1995). Moreover, follistatin, known to neutralize activin, has been observed to bind several BMPs (Iemura et al. 1998) and local concentrations of follistatin may be sufficient to complex with BMP and compete with activin. However, in the ewe pituitary BMPs do not exert an activin-like signal although, activin type II and type I (ALK-2 and ALK-4) receptors are expressed (Dupont et al. 2003) as well as follistatin (Farnworth et al. 1995). Rather, BMPs can stimulate their own receptors. Activation of BMP type I receptors (ALK-3 and ALK-6) is known to induce the phosphorylation of intracellular receptorspecific Smad proteins (R-Smad), Smad1, Smad5 and Smad8 (Miyazono et al. 2001). In ewe pituitary cells, we observed that phosphorylation of Smad1 occurred within $30 \mathrm{~min}$ of BMP addition. This result indicates that BMPs induce their own signaling pathway. Whether the activation of Smad1 is responsible for the decrease of FSH $\beta$ mRNA levels and FSH release has yet to be confirmed.

Upon phosphorylation of the R-Smad proteins, these latter associate with a common partner, Smad-4 and translocate to the nucleus. The complexes R-SmadSmad4 are then capable of binding DNA on a Smad binding element $(\mathrm{SBE})$. The regulation of target gene requires additional interaction with transcription factors, either coactivators or corepressors (for review, Massague \& Wotton 2000). Both SBEs and transcription factors may be cell type specific. For instance, a SBE was recently identified in the rat FSH $\beta$ subunit gene that is required for full activin responsiveness (Suszko et al. 2003). Interestingly, whereas this site is conserved in the mouse gene, it is not present in the ovine, bovine, porcine or human genes, suggesting that important species-specific differences exist in activin regulation of FSH $\beta$ gene expression. Similar differences probably exist in BMP regulation of target genes. Given that BMP-15 was found to stimulate the activity of ovine FSH $\beta$ promoter transfected in mouse $\mathrm{L} \beta \mathrm{T} 2$ gonadotrope cells, the presence of specific repressors rather than particular SBE in ovine gonadotropes could be favoured. Alternatively, because we did not determine whether BMPs act directly on FSH $\beta$ promoter, we cannot exclude the possibility that BMPs affect FSH production via another target gene in gonadotropes or other cell type. Further experiments will help to discern between these hypotheses.

Considering the inhibitory effect of BMPs on FSH secretion from ewe pituitary cells, we questioned whether BMPs can affect the stimulatory effect of activin, an essential regulator of FSH. Activin is produced by the pituitary and exerts a paracrine action on FSH secretion (for review, Padmanabhan \& McNeilly 2001). In the ewe, activin $\beta \mathrm{B}$-subunit and activin receptors are expressed by the gonadotropes themselves (Dupont et al. 2003, 


\section{BMP-4}
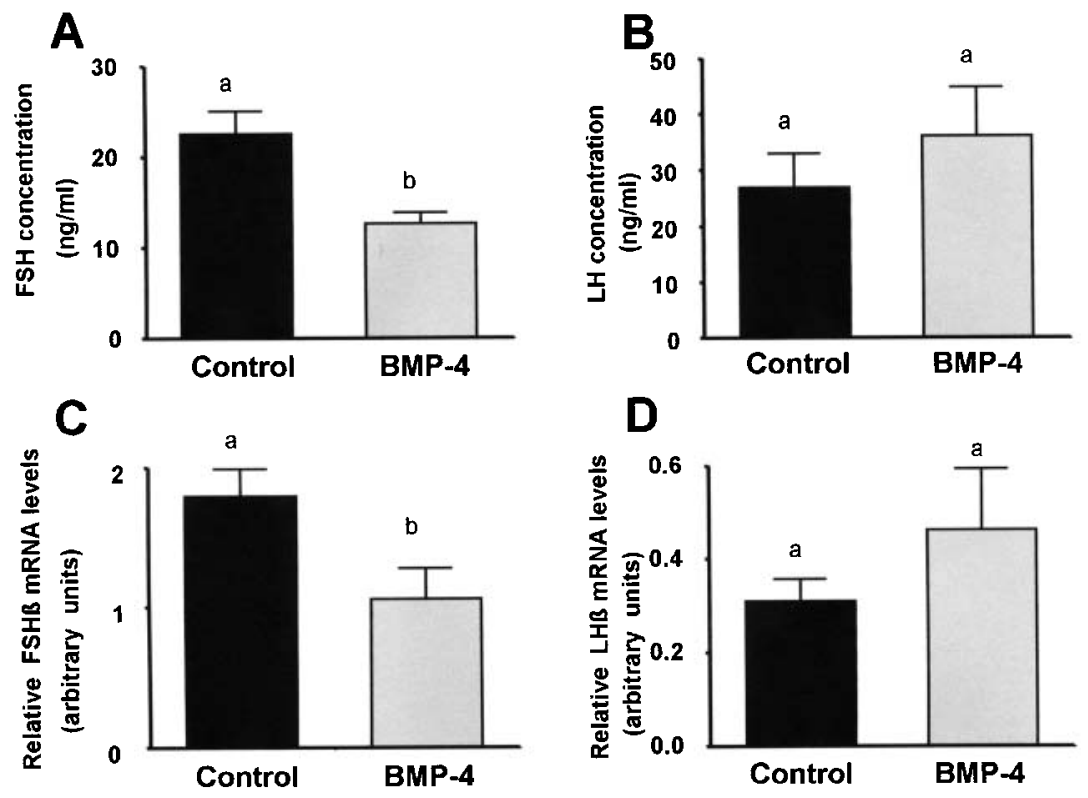

\section{BMP-6}
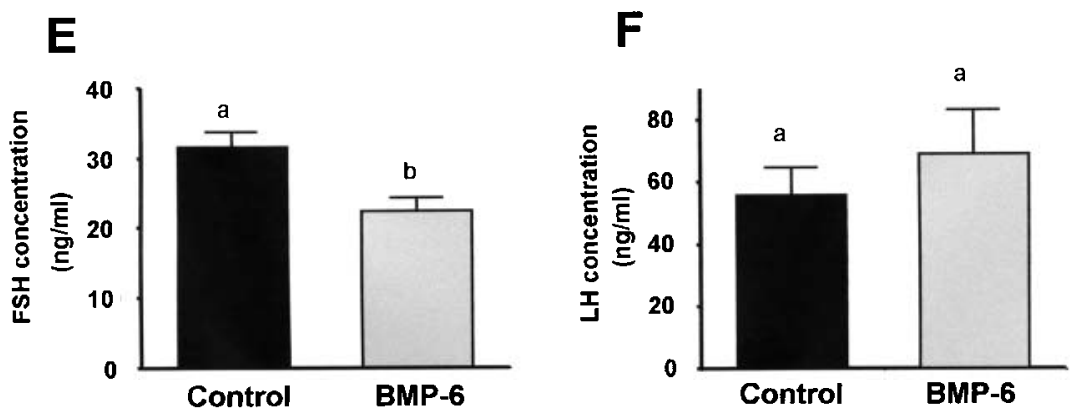

Figure 4 (I) Effect of BMP-4 on FSH (A) and $\mathrm{LH}(\mathrm{B})$ release and on FSH $\beta$ (C) and $\mathrm{LH} \beta$ (D) mRNA expression from ewe pituitary cells. Cells were cultured in serum-free medium for $48 \mathrm{~h}$ with $10^{-9} \mathrm{M}$ of BMP-4. Media were collected and the concentrations of FSH and $\mathrm{LH}$ were determined by ELISA. Values are the mean \pm S.E.M. from ten experiments. a vs $b$, $P<0 \cdot 01$. Cells were harvested and total mRNAs were extracted. A real time PCR was performed to detect the relative level of FSH $\beta$ or LH $\beta$ mRNA expression compared with the $18 \mathrm{~S}$ mRNA. Values are the mean \pm S.E.M. from one representative experiment with triplicate determinations. Three experiments were performed with similar results. $a$ vs $b$, $P<0 \cdot 05$. (II) Effect of BMP-6 on FSH (E) and LH (F) release from ewe pituitary cells. Cells were cultured in serum-free medium for $48 \mathrm{~h}$ with $2 \cdot 10^{-9} \mathrm{M}$ of BMP-6. Media were collected and the concentrations of FSH and $\mathrm{LH}$ were determined by ELISA. Values are the mean \pm S.E.M. from five experiments. $a$ vs $b, P<0 \cdot 05$.

McNeilly et al. 2003) and the production of activin was suggested by the findings of an activin bioactivity from pituitary cell conditioned media (F Mathoux, D J Phillips and C Taragnat, unpublished observations). The action of activin is modulated by antagonists, mainly follistatin and inhibin which abolish the effect of activin.
In our study, BMP-4 and BMP-6 (not shown) were found to antagonize the activin effect, suggesting that they can participate with other activin antagonists to regulate FSH synthesis and secretion. The precise mechanisms by which BMP and activin interact are under investigation. 


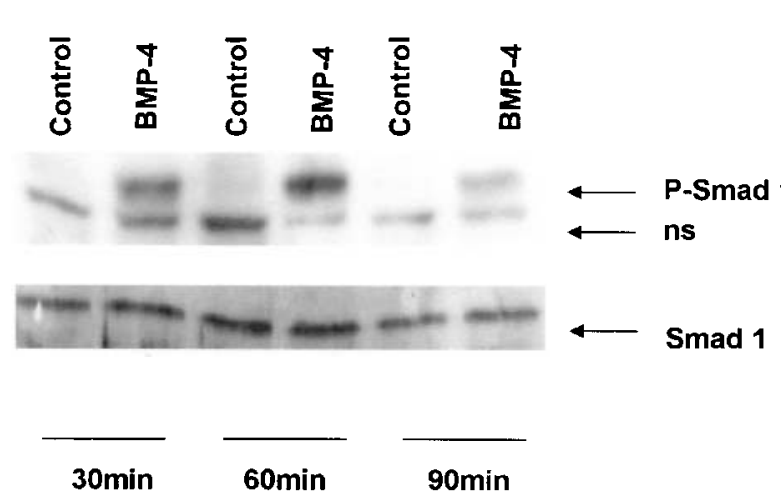

Figure 5 BMP-4 effect on Smad-1 phosphorylation. Pituitary cells were cultured in serum-free medium in presence or absence (control) of $10^{-9} \mathrm{M} \mathrm{BMP}-4$ for indicated times. Total proteins $(15 \mu \mathrm{g})$ were separated on $10 \%$ SDS-PAGE and transferred on PVDF membrane. Blots were probed with phospho-Smad1 antibody (upper) or with a Smad1 antibody (lower) and bands were revealed by ECL. ns refers to non specific.

Besides pituitary factors, another main regulator of FSH is estradiol. Estrogen receptors are expressed in gonadotropes in sheep (Sheng et al. 1998, Tobin et al. 2001) and injections of $17-\beta$ estradiol in ewes reduced FSH $\beta$ mRNA concentrations and FSH release directly at the pituitary level (Mercer et al. 1993, Phillips et al. 1998, Molter-Gérard et al. 2000). Moreover, the treatment of ovine pituitary cells with $17-\beta$ estradiol showed a direct negative effect on FSH promoter (Miller \& Miller 1996). In our study, estradiol also exerted a strong inhibition on FSH $\beta$ mRNA expression and FSH release. Moreover, BMP-4 amplified this effect of estradiol. In other tissues, it was shown that estrogens and BMPs could interact through overlapping intracellular signaling mechanisms (Yamamoto et al. 2002). In pituitary prolactinomas in rodent and human where BMP-4 as well as $17-\beta$ estradiol induces cell proliferation, an additive effect of both BMP-4 and 17- $\beta$ estradiol was observed (Paez-Pereda et al. 2003). In that model, Smad1 and Smad4 physically interacted with the estrogen receptor under BMP-4 stimulation (Paez-Pereda et al. 2003, Wu et al. 2003). A similar mechanism can occur in gonadotrope cells.

Whether BMP-4 exerts an inhibitory effect on FSH synthesis and release in vivo is not known at this date. In sheep, mutations have been identified either in BMPR-IB (ALK-6) in Booroola ewes (Mulsant et al. 2001, Souza et al. 2001, Wilson et al. 2001) or in BMP-15 in Inverdale and Hanna ewes (Galloway et al. 2000). Homozygous mutants for BMPR-IB and heterozygous mutants for BMP-15 exhibit a greater ovulation rate than wild type animals. Whether these mutants present changes in plasma FSH concentrations is a matter of controversy (McNatty et al. 1987, McNatty et al. 1991). However, we did not detect BMPR-IB in the gonadotrope cells. Hence, it is not surprising that the mutation does not significantly affect FSH release. We did not detect BMP-15 mRNA in the
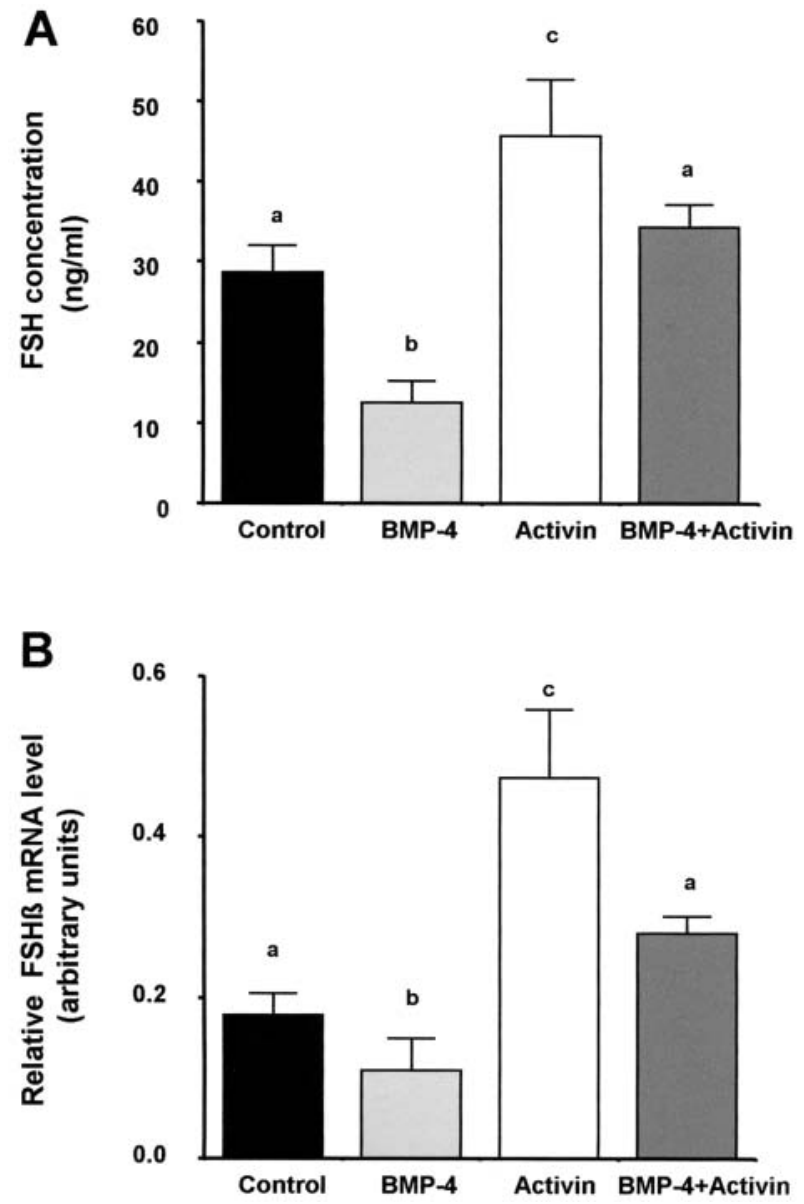

Figure 6 Interaction between BMP-4 and activin effects on FSH release (A) and FSH $\beta$ mRNA expression (B) in ewe pituitary cells. Cells were cultured in serum-free medium for $48 \mathrm{~h}$ in presence of $10^{-9} \mathrm{M} \mathrm{BMP}-4$ and/or $2 \times 10^{-9} \mathrm{M}$ activin. Media were collected and the concentrations of FSH were determined by ELISA. Cells were harvested and total mRNAs were extracted. A real time PCR was performed to detect the relative level of FSH $\beta$ mRNA expression compared with the $18 \mathrm{~S}$ mRNA (B). Values are the mean \pm S.E.M. from one representative experiment with triplicate determinations. Three experiments were performed with similar results. Bars with different letters indicate that group means are significantly different at $P<0 \cdot 05$.

pituitary, excluding the effect of the mutation at the pituitary level. Therefore, these mutation models are not suitable for understanding further the role of BMP-4 in FSH control.

In conclusion, BMP-4 and BMP-6 were shown to decrease FSH $\beta$ mRNA expression and FSH release from ewe pituitary cells and are able to antagonize the effects of activin, at least in vitro. These effects were not found on $\mathrm{LH}$ secretion. Moreover, the detection of BMP-2, BMP-4, BMP-7 and GDF-9 mRNAs in the pituitary as well as the colocalisation of both types of BMP receptors on gonadotrope cells suggest that these BMPs can exert 


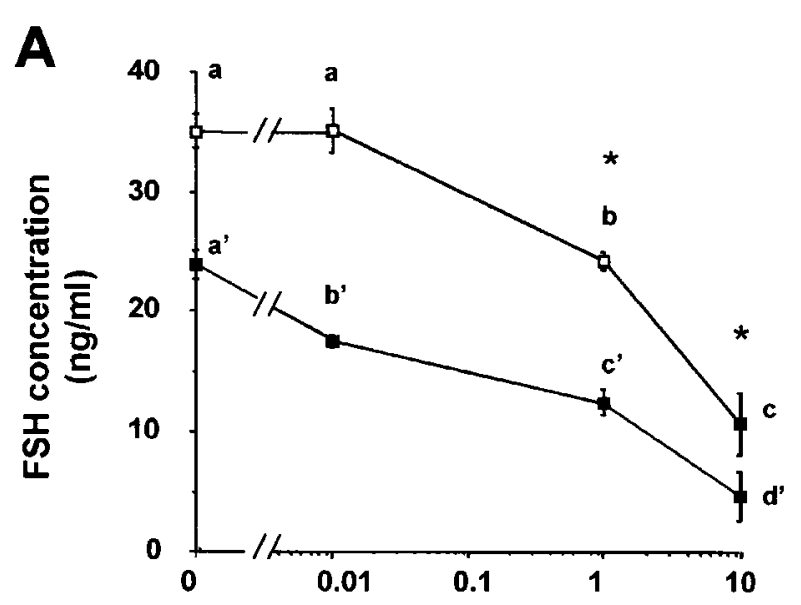

Estradiol concentration (pM)
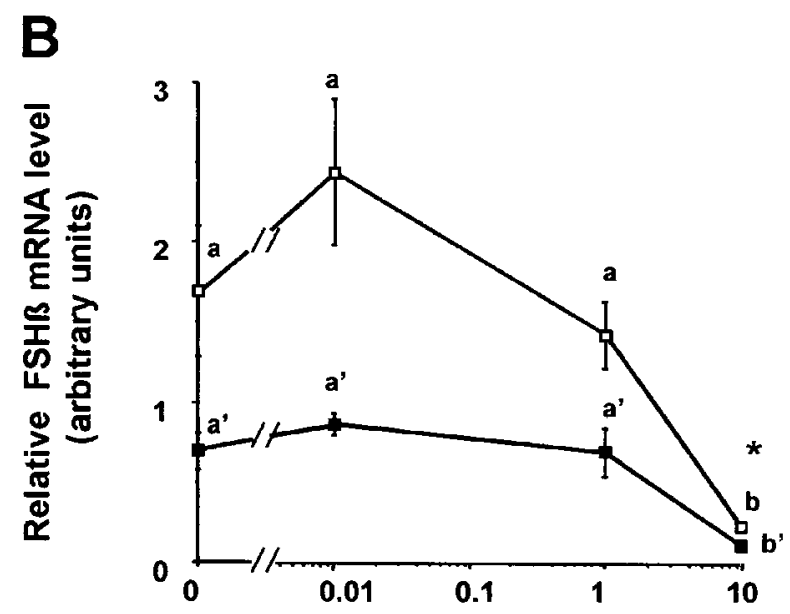

Estradiol concentration (pM)

Figure 7 Effect of $17-\beta$ estradiol in presence of BMP-4 on FSH release (A) and FSH $\beta$ mRNA expression (B) in ewe pituitary cells. Cells were cultured in serum-free medium for $48 \mathrm{~h}$ in the presence of indicated concentrations of $17-\beta$ estradiol with or without $10^{-9} \mathrm{M}$ of BMP-4. Media were collected and the concentrations of FSH were determined by RIA (A). Cells were harvested and total mRNAs were extracted. A real time PCR was performed to detect the relative level of FSH $\beta$ mRNA expression compared with the $18 \mathrm{~S}$ mRNA (B). Values are the mean \pm S.E.M. from one representative experiment with triplicate determinations and three experiments were performed with similar results. Different letters indicate that group means are significantly different at $P<0 \cdot 05$. *, $P<0 \cdot 05$ vs $17-\beta$ estradiol or BMP individually.

paracrine actions on FSH production modulating activin and/or estradiol action. Therefore, the findings of a functional BMP system in the ewe pituitary emphasize the role of BMPs in FSH control. Further experiments are required to establish the physiological importance of BMPs within the pituitary in the overall regulation of FSH synthesis and release.

\section{Acknowledgements}

We would like to thank Keith Henderson from Ag Research, Wallaceville Research Centre, Upper Hutt, New Zealand and Carl-Henrik Heldin from the Ludwig Institute for Cancer Research, Uppsala, Sweden for the gift of the BMP receptor antibodies. We thank Sylvie Canépa and Fabrice Mathoux for setting the oFSH ELISA assay, Ian Swanston and George Johnston for oFSH RIA technical assistance and Mhairi Laird and Sheila McPherson for immunohistochemistry technical assistance. We also thank the staff of INRA and MRC slaughterhouse and experimental farm for technical assistance. We acknowledge Judy McNeilly and Xavier Cayla for discussion.

\section{Funding}

This work was supported by Institut National de Recherches Agronomiques and by the Medical Research Council (Human Reproductive Sciences Unit, EH16 4SB, UK). MF was supported by a PhD fellowship from the Région Centre and by a fellowship for traveling from the Académie d'Agriculture de France and the Science and Technology Department of the French Embassy in the United Kingdom.

\section{References}

Bilezikjian LM, Blount AL, Corrigan AZ, Leal A, Chen Y \& Vale WW 2001 Actions of activins, inhibins and follistatins: implications in anterior pituitary function. Clinical and Experimental Pharmacology and Physiology 28 244-248.

Carroll RS, Corrigan AZ, Gharib SD, Vale W \& Chin WW 1989 Inhibin, activin, and follistatin: regulation of follicle-stimulating hormone messenger ribonucleic acid levels. Molecular Endocrinology 3 1969-1976.

Dalkin AC, Haisenleder DJ, Ortolano GA, Ellis TR \& Marshall JC 1989 The frequency of gonadotropin-releasing-hormone stimulation differentially regulates gonadotropin subunit messenger ribonucleic acid expression. Endocrinology 12 917-924.

Dasen JS, O'Connell SM, Flynn SE, Treier M, Gleiberman AS, Szeto DP, Hooshmand F, Aggarwal AK \& Rosenfeld MG 1999 Reciprocal interactions of Pit1 and GATA2 mediate signaling gradient-induced determination of pituitary cell types. Cell $\mathbf{9 7}$ 587-598.

De Kretser DM \& Robertson DM 1989 The isolation and physiology of inhibin and related proteins. Biology of reproduction 40 33-47.

Dirnhofer S, Madersbacher S, Bidart JM, Ten Kortenaar PB, Spottl G, Mann K, Wick G \& Berger P 1994 The molecular basis for epitopes on the free beta-subunit of human chorionic gonadotrophin (hCG), its carboxyl-terminal peptide and the hCG beta-core fragment. Journal of Endocrinology 141 153-162. 
Dupont J, McNeilly J, Vaiman A, Canepa S, Combarnous Y \& Taragnat C 2003 Activin signaling pathways in ovine pituitary and LbetaT2 gonadotrope cells. Biology of reproduction 68 1877-1887.

Ericson J, Norlin S, Jessel T \& Edlund T 1998 Integrated FGF and BMP signaling controls; the progression of progenitor cell differentiation and the emergence of pattern in the embryonic anterior pituitary. Development 125 1005-1015

Fabre S, Pierre A, Pisselet C, Mulsant P, Lecerf F, Pohl J, Monget P \& Monniaux D 2003 The Booroola mutation in sheep is associated with an alteration of the bone morphogenetic protein receptor-IB functonality. Journal of Endocrinology 177 435-444.

Farnworth PG, Thean E, Robertson DM \& Schwartz J 1995 Ovine anterior pituitary production of follistatin in vitro. Endocrinology 136 4397-4406.

Galloway SM, McNatty KP, Cambridge LM, Laitinen MP, Juengel JL, Jokiranta TS, McLaren RJ, Luiro K, Dodds KG, Montgomery GW, Beattie AE, Davis GH \& Ritvos O 2000 Mutations in an oocyte-derived growth factor gene (BMP15) cause increased ovulation rate and infertility in a dosage-sensitive manner. Nature Genetics 25 279-283.

Glister C, Kemp CF \& Knight PG 2004 Bone morphogenetic protein (BMP) ligands and receptors in bovine ovarian follicle cells: actions of BMP-4, -6 and -7 on granulosa cells and differential modulation of Smad-1 phosphorylation by follistatin. Reproduction 127 239-254.

Hanrahan JP, Gregan SM, Mulsant P, Mullen M, Davis GH, Powell R \& Galloway SM 2004 Mutations in the genes for oocyte-derived growth factors GDF9 and BMP15 are associated with both increased ovulation rate and sterility in Cambridge and Belclare sheep (Ovis aries). Biology of Reproduction 70 900-909.

Henderson KM, Camberis M \& Hardie AH 1995 Generation of monoclonal antibody to ovine FSH and its application in immunoneutralization and enzymeimmunoassay. Journal of Reproduction and Fertility Suppl 49 511-515.

Huang HJ, Wu JC, Su P, Zhirnov O \& Miller WL 2001 A novel role for bone morphogenetic proteins in the synthesis of folliclestimulating hormone. Endocrinology 142 2275-2283.

Iemura S, Yamamoto TS, Takagi C, Uchiyama $\mathrm{H}$, Natsume T, Shimasaki S, Sugino H \& Ueno N 1998 Direct binding of follistatin to a complex of bone-morphogenetic protein and its receptor inhibits ventral and epidermal cell fates in early Xenopus embryo. PNAS 95 9337-9342.

Kawabata M, Imamura T \& Miyazono K 1998 Signal transduction by bone morphogenetic proteins. Cytokine and Growth Factor Reviews 9 49-61.

Knight PG 1996 Roles of inhibins, activins, and follistatin in the female reproductive system. Frontiers of Neuroendocrinology 17 476-509.

Knight PG \& Glister C 2003 Local roles of TGF-b superfamily members in the control of ovarian follicle development. Animal Reproduction Sciences 78 165-183.

Lee WS, Otsuka F, Moore RK \& Shimasaki S 2001 Effect of bone morphogenetic protein-7 on folliculogenesis and ovulation in the rat. Biology of reproduction 65 994-999.

Lin SY, Morrison JR, Phillips DJ \& de Kretser DM 2003 Regulation of ovarian function by the TGF- $\beta$ superfamily and follistatin. Reproduction 126 133-148.

McNatty KP, Hudson N, Henderson KM, Gibb M, Morrison L, Ball K \& Smith P 1987 Differences in gonadotrophin concentrations and pituitary responsiveness to GnRH between Booroola ewes which were homozygous $(\mathrm{FF})$, heterozygous $(\mathrm{F}+)$ and non-carriers $(++)$ of a major gene influencing their ovulation rate. Journal of Reproduction and Fertility $80577-588$.

McNatty KP, Hudson NL, Shaw L, Condell LA, Ball K, Seah SL \& Clarke IJ 1991 GnRH-induced gonadotrophin secretion in ovariectomized Booroola ewes with hypothalamic-pituitary disconnection. Journal of Reproduction and Fertility 91 583-592.
McNeilly JR, McNeilly AS, Walton JS \& Cunningham FJ 1976 Development and application of a heterologous radioimmunoassay for ovine follicle-stimulating hormone. Journal of Endocrinology $\mathbf{7 0}$ 69-79.

McNeilly AS, Jonassen JA \& Fraser HM 1986 Suppression of follicular development after chronic LHRH immunoneutralization in the ewe. Journal of Reproduction and Fertility 76 481-490.

McNeilly AS, Crow W, Brooks J \& Evans G 1992 Luteinizing hormone pulses, follicle stimulating hormone and the control of follicle selection. Journal of Reproduction and Fertility Suppl 45 5-18.

McNeilly AS, Crawford JL, Taragnat C, Nicol L \& McNeilly JR 2003 The differential secretion of FSH and LH: regulation through genes, feedback and packaging. Reproduction Suppl 61 463-476.

Massague J \& Wotton D 2000 Transcriptional control by the TGF-beta/Smad signaling system. The EMBO journal 19 $1745-1754$.

Matteri RL, Roser JF, Baldwin DM, Lipovetsky V \& Papkoff H 1987 Characterization of a monoclonal antibody which detects luteinizing hormone from diverse mammalian species. Domestic Animal Endocrinology 4 157-165.

Mercer JE, Phillips DJ \& Clarke IJ 1993 Short-term regulation of gonadotropin subunit mRNA levels by estrogen: studies in the hypothalamo-pituitary intact and hypothalamo-pituitary disconnected ewe. Journal of Neuroendocrinology 5 591-596.

Miller CD \& Miller WL 1996 Transcriptional repression of the ovine follicle-stimulating hormone- beta gene by 17 beta-estradiol. Endocrinology 137 3437-3446.

Miyazono K, Kusanagi K \& Inoue H 2001 Divergence and convergence of TGF-beta/BMP signaling. Journal of Cellular Physiology 187 265-276.

Molter-Gerard C, Fontaine J, Guerin S \& Taragnat C 1999 Differential regulation of the gonadotropin storage pattern by gonadotropin-releasing hormone pulse frequency in the ewe. Biology of Reproduction 60 1224-1230.

Molter-Gerard C, Caraty A, Guerin S, Fontaine J \& Taragnat C 2000 Dynamic changes in the gonadotrope cell subpopulations during an estradiol-induced surge in the ewe. Biology of Reproduction $\mathbf{6 3}$ 1084-1091.

Mulsant P, Lecerf F, Fabre S, Schibler L, Monget P, Lanneluc I, Pisselet C, Riquet J, Monniaux D, Callebaut I, Cribiu E, Thimonier J, Teyssier J, Bodin L, Cognie Y, Chitour N \& Elsen JM 2001 Mutation in bone morphogenetic protein receptor-IB is associated with increased ovulation rate in Booroola Merino ewes. PNAS 98 5104-5109.

Otsuka F \& Shimasaki S 2002 A novel function of bone morphogenetic protein-15 in the pituitary: selective synthesis and secretion of FSH by gonadotropes. Endocrinology 143 4938-4941.

Otsuka F, Yao Z, Lee T, Yamamoto S, Erickson GF \& Shimasaki S 2000 Bone morphogenetic protein-15. Identification of target cells and biological functions. The Journal of Biological Chemistry 275 39523-39528.

Padmanabhan V \& McNeilly AS 2001 Is there an FSH-releasing factor? Reproduction 121 21-30.

Paez-Pereda M, Giacomini D, Refojo D, Nagashima AC, Hopfner U, Grubler Y, Chervin A, Goldberg V, Goya R, Hentges ST, Low MJ, Holsboer F, Stalla GK \& Arzt E 2003 Involvement of bone morphogenetic protein 4 (BMP-4) in pituitary prolactinoma pathogenesis through a Smad/estrogen receptor crosstalk. PNAS $1001034-1039$.

Phillips CL, Lin LW, Wu JC, Guzman K, Miloted A \& Miller WL $199817 \beta$-estradiol and progesterone inhibit transcription of the genes encoding the subunits of ovine follicle-stimulating hormone. Molecular Endocrinology 2 641-649.

Rosenzweig BL, Imamura T, Okadome T, Cox GN, Yamashita H, ten Dijke P, Heldin CH \& Miyazono K 1995 Cloning and characterization of a human type II receptor for bone morphogenetic proteins. PNAS $927632-7636$. 
Sheng C, McNeilly AS \& Brooks AN 1998 Distribution of estrogen receptor a and luteinizing hormone $\beta$ subunit in the ovine pituitary gland during fetal development. Journal of Neuroendocrinology 10 713-718.

Shimasaki S, Zachow RJ, Li D, Kim H, Iemura S, Ueno N, Sampath K, Chang RJ \& Erickson GF 1999 A functional bone morphogenetic protein system in the ovary. PNAS 96 7282-7289.

Shimasaki S, Moore RK, Otsuka F \& Erickson GF 2004 The bone morphogenetic protein system in mammalian reproduction. Endocrine Reviews 25 72-101.

Souza CJ, MacDougall C, MacDougall C, Campbell BK, McNeilly AS \& Baird DT 2001 The Booroola (FecB) phenotype is associated with a mutation in the bone morphogenetic receptor type $1 \mathrm{~B}$ (BMPR1B) gene. Journal of Endocrinology 169 R1-R6.

Souza CJ, Campbell BK, McNeilly AS \& Baird DT 2002 Effect of bone morphogenetic protein 2 (BMP2) on oestradiol and inhibin A production by sheep granulosa cells, and localization of BMP receptors in the ovary by immunohistochemistry. Reproduction $\mathbf{1 2 3}$ 363-369.

Souza CJ, Campbell BK, McNeilly AS \& Baird DT 2003 Bone morphogenetic proteins and folliculogenesis: lessons from the Booroola mutation. Reproduction Suppl 61 361-370.

Suszko MI, Lo DJ, Suh H, Camper SA \& Woodruff TK 2003 Regulation of the rat follicle-stimulating hormone beta-subunit promoter by activin. Molecular Endocrinology 17 318-332.

Takuma N, Sheng HZ, Furuta Y, Ward JM, Sharma K, Hogan BLM, Pfaff SL, Westphal H, Kimura S \& Mahon KA 1998 Formation of Rathke's pouch requires dual induction from the diencephalons. Development 125 4835-4840.

ten Dijke P, Yamashita H, Ichijo H, Franzen P, Laiho M, Miyazono K \& Heldin CH 1994 Characterization of type I receptors for transforming growth factor-beta and activin. Science 264 101-104.

Tobin VA, Pompolo S \& Clarke IJ 2001 The percentage of pituitary gonadotropes with immunoreactive oestradiol receptors increases in the follicular phase of the ovine oestrous cycle. Journal of Neuroendocrinology 13 846-854.
Welt C, Sidis Y, Keutmann H \& Schneyer A 2002 Activins, Inhibins, and Follistatins: from endocrinology to signaling. A paradigm for the new millennium. Experimental Biology and Medecine (Maywood) 227 724-752.

Wilson T, Wu XY, Juengel JL, Ross IK, Lumsden JM, Lord EA, Dodds KG, Walling GA, McEwan JC, O'Connell AR, McNatty KP \& Montgomery GW 2001 Highly prolific Booroola sheep have a mutation in the intracellular kinase domain of bone morphogenetic protein IB receptor (ALK-6) that is expressed in both oocytes and granulosa cells. Biology of Reproduction $\mathbf{6 4}$ $1225-1235$.

Wu L, Wu Y, Gathings B, Wan M, Li X, Grizzle W, Liu Z, Lu C, Mao Z \& Cao X 2003 Smad4 as a transcription corepressor for estrogen receptor $\alpha$. Journal of Biological Chemistry 278 15192-15200.

Yamamoto T, Saatcioglu F \& Matsuda T 2002 Cross-talk between bone morphogenetic proteins and estrogen receptor signaling. Endocrinology 143 2635-2642.

Yamashita H, ten Dijke P, Huylebroeck D, Sampath TK, Andries M, Smith JC, Heldin CH \& Miyazono K 1995 Osteogenic protein-1 binds to activin type II receptors and induces certain activin-like effects. The Journal of Cell Biology 130 217-226.

Yan C, Wang P, DeMayo J, DeMayo FJ, Elvin JA, Carino C, Prasad SV, Skinner SS, Dunbar BS, Dube JL, Celeste AJ \& Matzuk MM 2001 Synergistic roles of bone morphogenetic protein 15 and growth differentiation factor 9 in ovarian function. Molecular Endocrinology 15 854-866.

Zwijsen A, Verschueren K \& Huylebroeck D 2003 New intracellular components of bone morphogenetic protein/Smad signaling cascades. FEBS letters 546 133-139.

Received 29 March 2005

Accepted 8 April 2005

Made available online as an Accepted Preprint 21 April 2005 